Teaching \& Learning (2013/2014) 8(1), 35-55

\title{
Learning Benefits for K-5 Students with Pets and Other Living Organisms on the Environmental Playground
}

\author{
ROBIN McCARTNEY \\ University of Louisiana, Lafayette \\ DONNA WADSWORTH \\ University of Louisiana, Lafayette
}

\begin{abstract}
This paper describes an environmental research project investigating the learning benefits for 380 elementary (K-5) students, 49 teacher candidates, and 18 teachers, when classroom pets and other living organisms were included on the school's new environmental playground. Teacher candidates from a local university completed field experiences, focusing on student learners' experiences during class time and on the playground. Data sources included interviews, exit questions, reflective journals, and photographs from the perspective of teacher candidates, regarding (K-5) students, and teachers. Results suggested that children are making connections to responsibility, respect, nurturing, and knowledge of animal life on and off the playground.
\end{abstract}

\section{Introduction}

Children are typically curious and motivated to explore in a natural setting (Green Schoolyards, 2010). However, some children, due to diverse backgrounds in home experiences, may be apprehensive to interact with the animal life in that natural setting. Ascione (1992) revealed that children who are exposed to animals, will have more positive dispositions regarding animals. Inagaki (1990) agreed, and suggested that children who have been exposed to pets are also more adapted to involvement and interest with living creatures in the natural world. Children may be encouraged to feel more confident with nurturing and understanding pet behaviour through interaction, and inquiry at school (Ross, 1997). Playful discovery with live creatures in science learning may "promote positive attitudes, lay the foundation for simple science concepts and stimulate the development of such process skills as observation, comparison, classification, prediction, and interpretation” (Rogers, Martin, \& Kousaleos, 1988, p. 21). The National Wildlife Federation highlighted the need for responsible behaviours regarding animal life to be instilled at an early age, because research reveals students develop 
skills in environmental sciences simultaneously (Coyle, 2010). Therefore, projects, such as an 'environmental playground,' where student learners can interact with classroom pets and wildlife in the environment, may be an innovative solution to changing student attitudes, and enhancing knowledge about animal care, allowing them to make informed decisions about safety with all living organisms in the environment, as recommended by the National Science Teachers Association (2008).

Environmental playgrounds are designed to encourage the exploration of a natural habitat representative of the surrounding area, encouraging inquiry discovery, exploration, collaboration, and safety, with regard to pets (National Research Council, 2011), as well as supporting scientific process skill development, such as observation, communication, making real world connections to animal life, responsibility, and problem-solving, as suggested by the state curriculum documents and the national science standards (NSTA, 2008).

This paper will describe the experience of 380 elementary school children (Grades K-5) in southern Louisiana, with a new environmental school playground funded by a federal grant (Magnet School A+ Access, 2007), and the perceived learning benefits for those students involved.

\section{Methods}

The purpose of this research study was to investigate learning benefits students experienced from the inclusion of classroom pets, and other living organisms on the school's new environmental playground. There were three groups of participants: 49 teacher candidates from a local university performing field experiences, 380 K-5 student learners, and 18 teachers at the school. The setting was a small, low socioeconomic elementary school, with a diverse population. Qualitative methods were used to answer the following research question: What are the learning benefits for K-5 learners, who experienced instruction that included pets and other living organisms, from the perspectives of teacher candidates, students, and teachers?

Data collection included interviews, teacher candidate response journals, and observations. Exit questions given to teacher candidates, student learners, and teachers, also served as data. 


\section{Response Journals}

Teacher candidates were taught how to conduct random interviews of K-5 students, using open-ended questions (Holstein \& Gubrium, 1995). This particular model focuses on the importance of exploration before explanations of concepts. Informal interviews with K-5 students were conducted regarding their perceptions of pets, the environmental playground, and the connection to what they had learned in the classroom. Teacher candidates were asked to listen to the responses of the students they were interviewing, record conversations, and photograph and note activities related to this study with pets. Teacher candidates were taught how to integrate the 6E Inquiry Learning Model into their interview questions, and were expected to show evidence of its use in their Response Journals (Trowbridge \& Bybee, 1990).

\section{Exit Questions}

The questions were administered to all participants: teacher candidates, K-5 students, and teachers. The researchers constructed questions for all three groups, regarding both cognitive and affective characteristics. For example, an affective question was: "How do the pets make you feel?"

The K-3 students were given pictures and asked to circle answers. The fourth and fifth graders were given open-ended questions, which included: "How do you feel about pets in your classroom? Why?" "Name your favorite activity on the playground?" "What are the advantages of having pets on the playground?” The classroom teachers administered all exit questions.

Additionally, the teacher candidates were given exit questions. Some sample questions were: "During your field experience related to animal life did you notice cognitive differences in the student populations? Explain.” "During your field experiences did you notice affective differences in the student populations? Explain.” "Did each grade level seem to have favorite activities?” "Describe a favorite moment or success story."

Descriptive information to discover teachers’ perceptions regarding instructional practices related to animals and living organisms, was collected from questions such as, "How have pets enhanced the affective and cognitive learning within the curriculum at school?’ 


\section{The Environmental Playground}

At the school selected for this study, the environmental playground contained several natural organisms, including many insects commonly found in the area (e.g., ladybugs, ants, snails, beetles, 'roly-polys'- an informal name for isopod crustaceans, and other creatures in their natural habitats). Ecosystems were also created for turtles and butterflies on the playground. Additionally, habitats for classroom pets (two rabbits, two adult dogs and five puppies, one parakeet, ten types of tank fish, one dragon Pogona lizard, three gerbils, four guinea pigs, and two hamsters) were student-constructed. Figures 1 and 2 portray children investigating and discovering various habitats in the environmental playground.

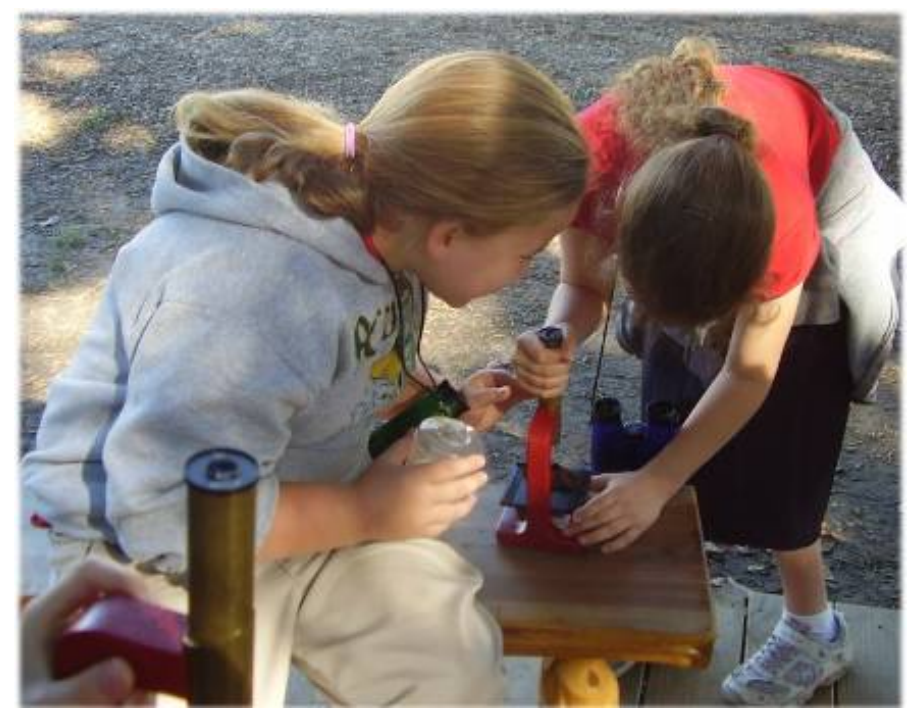

Figure 1: Students exploring the microscopic view of bugs

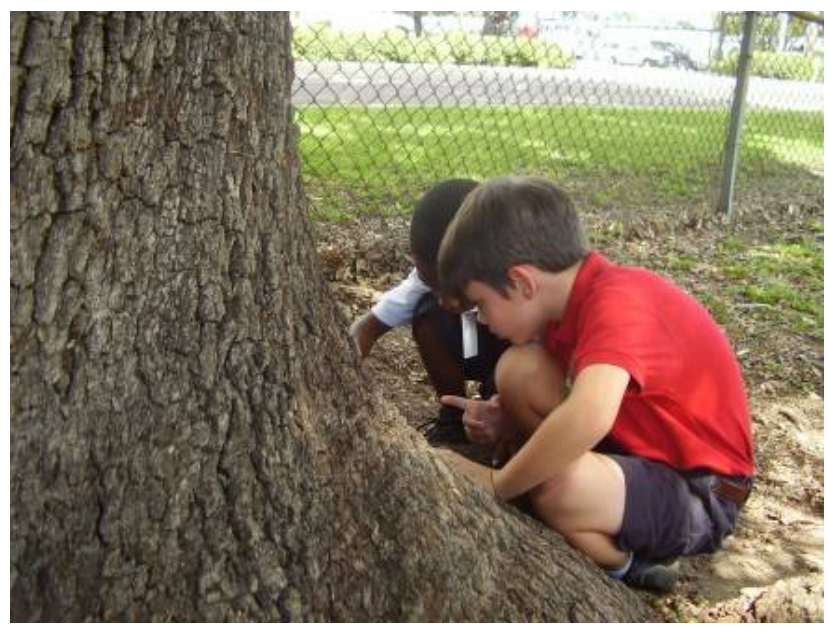

Figure 2: Children investigating the habitats of ants 
The outdoor classroom provided opportunities for authentic learning experiences, and an avenue to develop process skills, such as observation of animal life, habitats, adaptations, and various life cycles of pets and insect life (Cronin-Jones, 2000). Self-instruction was introduced as a learning strategy in the classroom; students were then encouraged to observe and elaborate using this process on the playground (Figures 3 and 4).

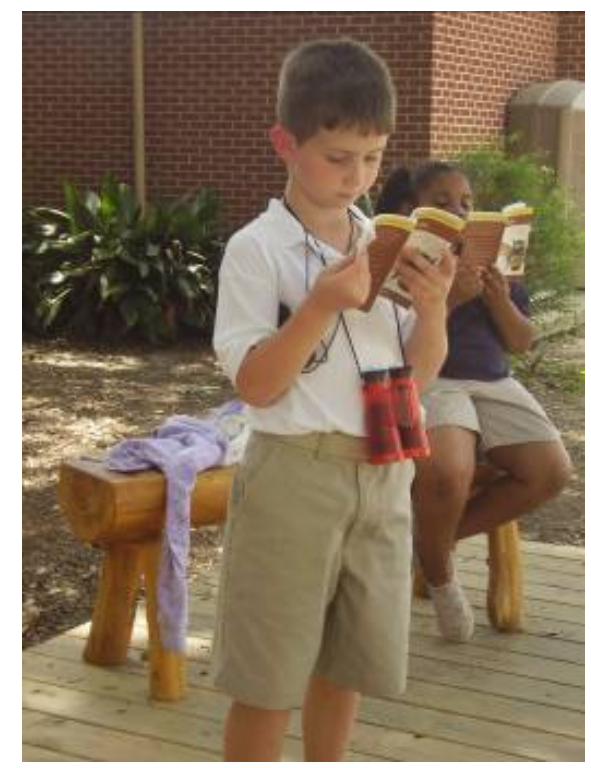

Figure 3: Self-instruction - Using Reference Guides

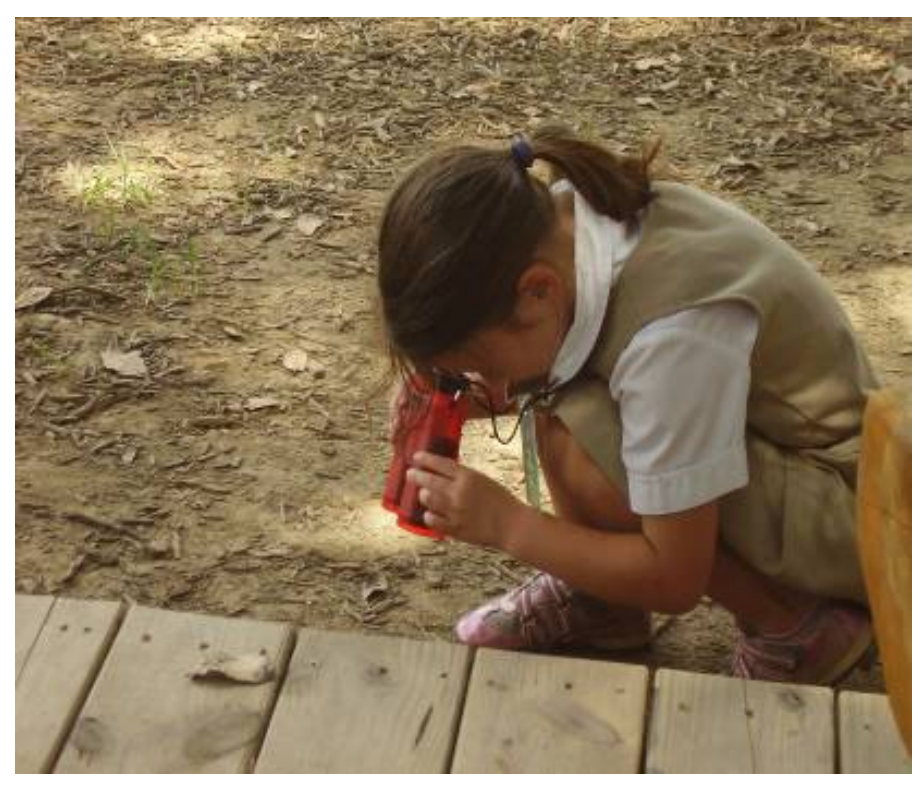

Figure 4: Using Observation 
In addition, students explored nature using equipment including microscopes, butterfly nets, binoculars, etc. Students were encouraged to engage in self-instruction. When resources were provided, the students, like professional scientists, observed animals, and simultaneously recorded observations in their journals. Table 1 describes the types of classroom activities that were conducted on the environmental playground.

Table 1

Sample Activities Connecting the Classroom to the Environmental Playground

\begin{tabular}{|c|c|c|c|c|c|}
\hline $\begin{array}{l}\text { Grade } \\
\text { level }\end{array}$ & $\begin{array}{l}\text { Station } \\
\text { focus } \\
\text { outside }\end{array}$ & $\begin{array}{l}\text { Subject } \\
\text { objective } \\
\text { GLE }\end{array}$ & $\begin{array}{l}\text { Indoor } \\
\text { activity }\end{array}$ & $\begin{array}{l}\text { Outdoor } \\
\text { connection }\end{array}$ & $\begin{array}{l}\text { Expected } \\
\text { outcomes }\end{array}$ \\
\hline $\begin{array}{l}\text { Grades 3- } \\
4-5\end{array}$ & $\begin{array}{l}\text { Whole } \\
\text { outdoor } \\
\text { playground. }\end{array}$ & $\begin{array}{l}\text { Students will } \\
\text { investigate the } \\
\text { impact of } \\
\text { environmental } \\
\text { conditions on } \\
\text { animal } \\
\text { movement. }\end{array}$ & $\begin{array}{l}\text { Snail race } \\
\text { with } 2 \text { snails. } \\
\text { Objective is } \\
\text { to encourage } \\
\text { movement of } \\
\text { snails by } \\
\text { using spray } \\
\text { bottles filled } \\
\text { with water. } \\
\text { The track was } \\
\text { made of a } \\
\text { smooth } \\
\text { plastic. } \\
\text { Describe and } \\
\text { explain the } \\
\text { results. }\end{array}$ & $\begin{array}{l}\text { Race } 2 \text { snails } \\
\text { over a dirt } \\
\text { surface on the } \\
\text { playground } \\
\text { using the } \\
\text { same method } \\
\text { and time } \\
\text { period as an } \\
\text { indoor } \\
\text { activity. } \\
\text { Make a } \\
\text { prediction. } \\
\text { Describe and } \\
\text { explain the } \\
\text { results. }\end{array}$ & $\begin{array}{l}\text { Hypothesis: } \\
\text { Snails in } \\
\text { their natural } \\
\text { habitat will } \\
\text { go faster OR } \\
\text { Snails on } \\
\text { smooth } \\
\text { surfaces will } \\
\text { go faster } \\
\text { with less } \\
\text { friction. }\end{array}$ \\
\hline $\begin{array}{l}\text { All } \\
\text { grades }\end{array}$ & Nature Trail & $\begin{array}{l}\text { Students will } \\
\text { classify natural } \\
\text { artifacts and } \\
\text { artistically } \\
\text { place them in a } \\
\text { collage by } \\
\text { using treasures } \\
\text { found. }\end{array}$ & $\begin{array}{l}\text { Arrange or } \\
\text { classify } \\
\text { natural } \\
\text { collected } \\
\text { artifacts. } \\
\text { Consider } \\
\text { characteristics } \\
\text { of objects, } \\
\text { how it made } \\
\text { you feel, and } \\
\text { why. Record. }\end{array}$ & $\begin{array}{l}\text { Concentrate } \\
\text { on collecting } \\
\text { a variety of } \\
\text { samples from } \\
\text { nature, } \\
\text { including } \\
\text { different } \\
\text { colors and } \\
\text { textures. }\end{array}$ & $\begin{array}{l}\text { The creation } \\
\text { of final } \\
\text { products } \\
\text { with } \\
\text { potential } \\
\text { gains in } \\
\text { knowledge } \\
\text { and aesthetic } \\
\text { appreciation. }\end{array}$ \\
\hline
\end{tabular}

Classroom pets were taken outside at designated times, and children took turns with caretaking responsibilities. As the children's age increased, pets selected for participation involved more complex activities, responsibility, and care. For example, at the kindergarten level, students 
were mainly exposed to various fish in tanks. They also had a guinea pig and a hamster that were shared between kindergarten classrooms. First and second graders maintained numerous tank fish, plus a Central American wood turtle, and a blue tiger shark. The third grade shared a guinea pig and a hermit crab. Fourth grade shared several fish, a rabbit, a parakeet, and two adult Chihuahuas with five puppies. The fifth graders looked after angelfish, Beta fish, a bearded dragon Pogona lizard, a rainbow shark, and another wood turtle. In all grades, students, parents, and teachers, supervised pets during holidays.

\section{Data Analysis}

Interviews and response journals from teacher candidates were transcribed and analyzed independently by two researchers, using thematic textual analysis (Patton, 2002), in which comments were unitized to their smallest, recognizable component. These notations were sorted into emergent categories, by assigning codes to each set of unitized data. Themes emerged from further analysis of categories, providing insights into the impact of the student learner experience on the three groups of participants. A sample of the emergent coding process is provided in Appendix A, to illustrate how unitized data from data sources, such as teacher candidates’ reflective journals, were coded, then organized into key descriptor phrases. These phrases were grouped into general categories for each participant group. Descriptive statistics were gathered from the exit questions, given to all participants, and were analyzed according to frequency count patterns and percentages.

Although findings from this type of analysis are not generalizable, the themes and patterns identified as relevant to this type of experience may be transferable to similar situations (Lincoln \& Guba, 1985). Credibility of findings is ensured through the use of multiple data sources providing triangulation.

\section{Findings}

The learning benefits derived from experiences with pets and other living organisms on the environmental playground, revealed several themes. These included: interest in pets and other animal life, nurturing and responsibility behaviours with pets, curiosity, exploration, reflection, concrete experience to support conceptual learning, and increased self-esteem. 


\section{Teacher Candidate Response Journals and Exit Questions}

Teacher candidate response journals provided extensive information for this research project. Researchers noticed in all journals, the enormous student interest in pets and other animal and insect life. The playground manipulatives seemed to motivate the inquiry process, especially the newly discovered interest in birds and insects. Curiosity may have been stimulated due to exposure to microscopes, hand lenses, and other equipment. The living organisms were always there, but students had not been encouraged to investigate living organisms using equipment. One example of a teacher candidate’s reflection in her field notes, captured the following conversation:

The teacher suddenly blew her whistle for a 20 second 'Nature Break.' Everyone stopped playing and focused on something in nature to observe and record. Watching children learn while at play is an amazing experience! One girl had a piece of tree bark in her hand. While looking at it closely she exclaimed, 'It looks exactly like a buffalo!' While turning it over bugs began crawling out of it. The other students excitedly grabbed a microscope from a nearby cabinet. Another child screamed 'Ew! Nasty!' Everyone ran to look. A snail was moving slowly across the concrete leaving a trail of slime. They all decided observation was very cool.

Teacher candidates were provided guidelines for journaling, and encouraged to be only participant observers. Their interaction with students was limited to inquiry, and interviews of the K-5 student population. Some of their statements represented themes identified in each of the questions.

Question - Did you notice any cognitive differences in student behaviour and conversations on the playground compared to the classroom?

- "Students were using equipment and writing about characteristics of bug life cycles."

- "Students knew a lot more about pets and insects than most students I have encountered."

- “They knew all about bees and how they pollinate.” 
- "Students learned about various birds by looking through binoculars."

Question - Did you notice any affective differences in student behaviour and conversations on the playground compared to the classroom?

- "Students were very sensitive and respectful toward nature and the environment."

- "Compared to other schools, children were more excited and engaged.”

- "Children were very protective of their pets."

Question - Did the playground promote stewardship?

- "Most children loved taking care of the pets."

- "Planned events for family and community to help with pets."

- "One student wanted to take the wings off of a fly and another student stopped her."

- “Students were careful not to step on bugs.”

Question - What are the strengths/weaknesses of the playground?

- Strengths:

- "Many learning opportunities including observation of life cycles, adaptations, and habitats.”

- “Development of process skills.”

- "Responsibility."

- “Care-taking."

- Weaknesses:

- “Time constraints."

- “Time caring for pets.”

- "Noise."

Question - Did the student learners teach you things about the playground?

- “The children taught me facts that I did not know.”

- "I learned that hermit crabs have modified lungs." 
- "I learned too much to list! They taught me about insects, animals, and so much more.”

Question - Would you prefer to teach at a school with an environmental playground? $78 \%$ said “yes”. If yes, why?

- "To see the excitement in their eyes when they played with the puppies."

- "To watch them get so excited to see a ladybug."

- "To watch them care for snails."

- “To see them clean an animal’s cage and not complain.”

- "To see why the hamster was making so much noise."

Question - What were the overall favorite activities?

- “Older students had buckets and they were catching frogs.”

- "A tour of the butterfly garden and turtle station."

- "I liked hearing the real life stories about pets."

- "Placing bugs in a container with a magnifying glass.”

- “Comparing insects to pictures in a book."

- "I loved that the children were able to play with the dogs and the rabbits."

- "My favorite was the cabinet full of equipment for learning."

Above all, teacher candidates recorded that they learned to ask questions, and felt at ease conversing with students. Pictures of some of their observations are included in Figures 5-8. 
Learning Benefits for K-5 Students

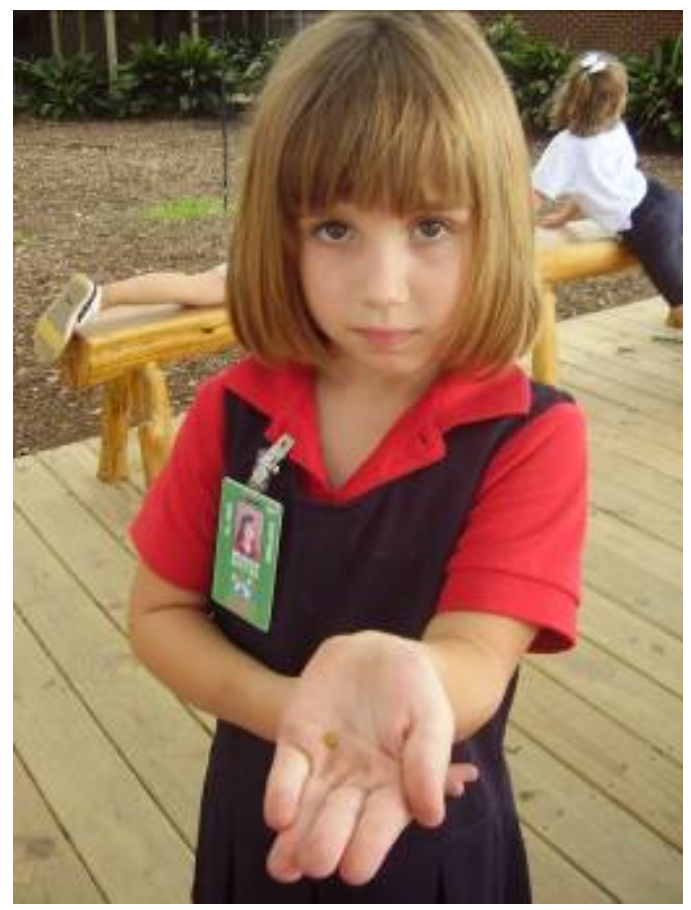

Figure 5: Lady Bug Found!

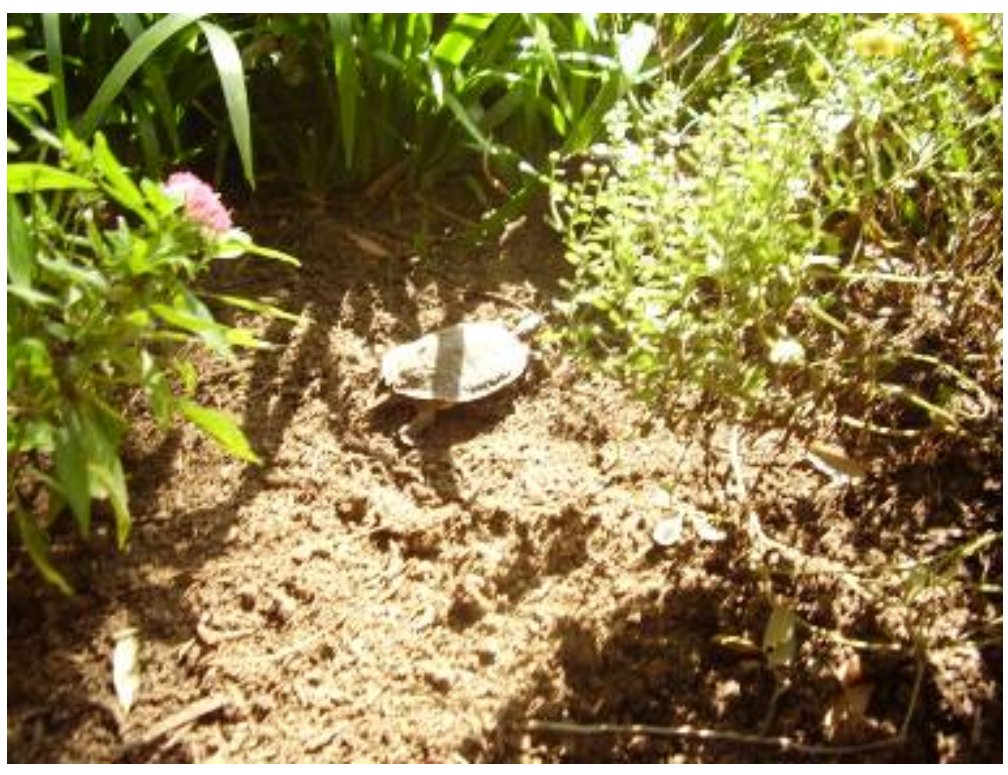

Figure 6: How slow can they go? 


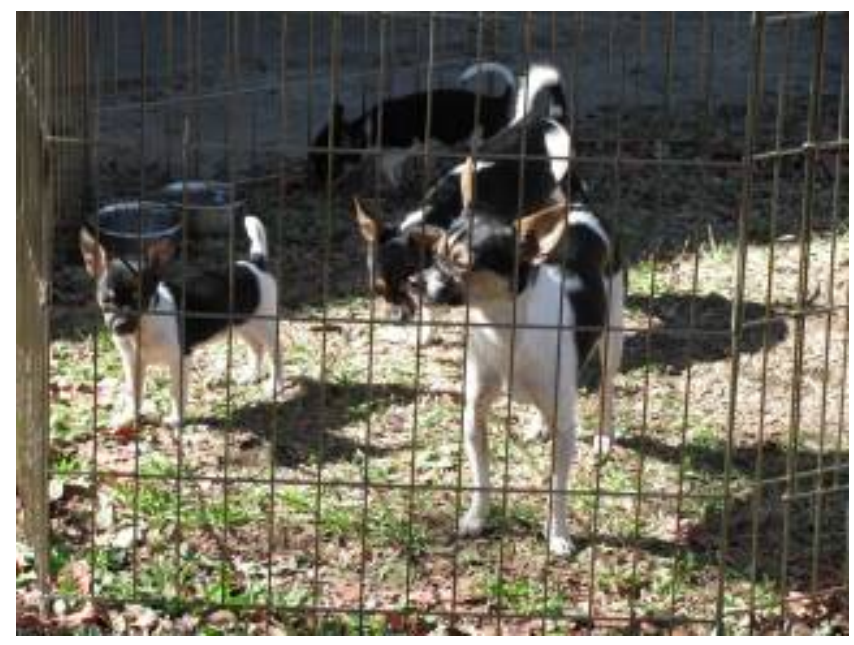

Figure 7: Dogs at school?

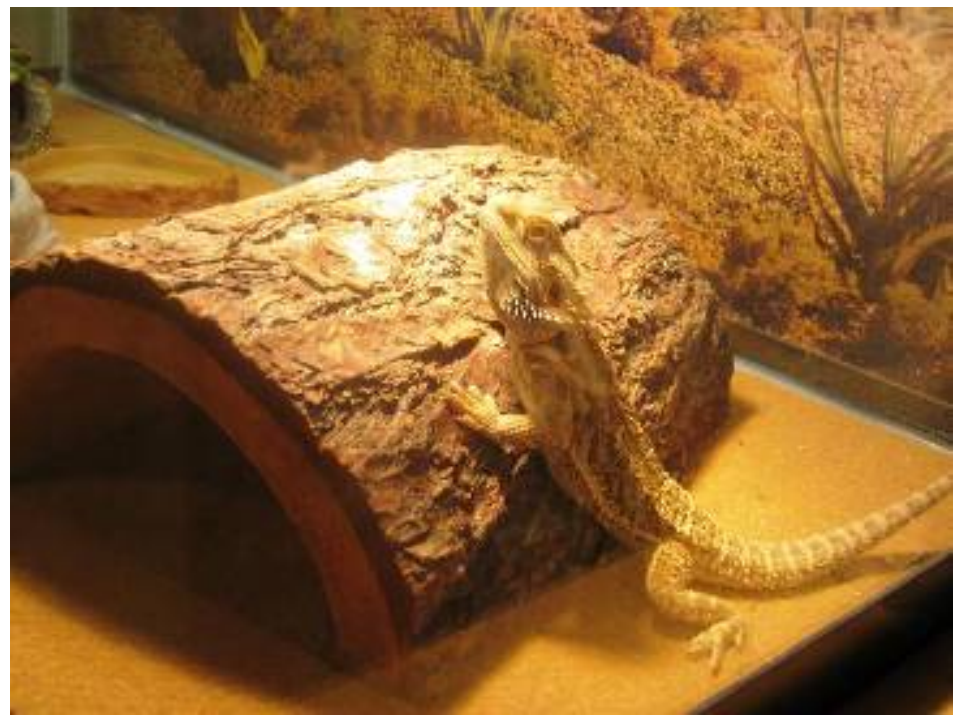

Figure 8: Who's observing whom?

Teacher candidates were amazed how much information the students taught them on a daily basis. One mentioned that "the children taught me facts that I did not know." Others indicated in their journals their perceptions that the K-5 student learners seem to have a greater knowledge of science than their own. The value of how this experience (interacting with children, observing pets, equipment, and an environmental focused playground) could be used to enhance teacher candidate knowledge of science, was also described. 


\section{K-5 Student Exit Questions}

Data analysis revealed that there were several benefits to having students engage with animals in the environmental playground. Affectively, the student learners overwhelmingly indicated that even with the requirements of real world responsibilities for these animals, having pets in the school was valued by all grade levels (see Table 2).

Table 2 K-5 student preferences for including pets in the classroom

\begin{tabular}{|l|l|l|l|l|l|l|}
\hline $\begin{array}{l}\text { Grade } \\
\text { Levels }\end{array}$ & $\mathrm{K}$ & 1 & 2 & 3 & 4 & 5 \\
\hline Percentage & $93 \%$ & $93 \%$ & $97 \%$ & $96 \%$ & $97 \%$ & $97 \%$ \\
\hline
\end{tabular}

Fourth and fifth grade students were asked to write a response to: "How do you feel about pets in the classroom?” The student comments in Table 3 reveal their overall enjoyment with having pets at school, and often used terms such as love, great, and special. The students' comments indicated exposure to real world responsibilities, because they saw directly that animals kept indoors depended on humans to keep them clean, watered, fed, and healthy, as opposed to insects who instinctively know how to take care of themselves. Some students considered animals to be companions, and felt like they were friends. The pets provided play opportunities for children. Students were involved in discovery and learned content, such as protective coloration, and various life cycle stages.

Table 3

$4^{\text {th }}$ and $5^{\text {th }}$ grade participants' open-ended comments

- I really love having pets but in my opinion they adore us too much and can distract us.

- I feel it is a great opportunity to learn from pets.

- If I can’t play with my friend I can play with the dogs.

- I don't like it because they make noises.

- I love taking the hamster outside to watch where he goes.

- I love having pets because you can investigate.

- I feel great because if we finish our work we get to play with the pets.

- I feel special because not all kids get class pets.

- I love having pets because we learn responsibility. This will teach us to take care of our own children. 


\section{Teacher Exit Questions}

Teacher exit questions revealed several benefits from the student experiences with pets and other living organisms on the environmental playground.

When teachers were asked, "Do you think the use of pets and living organisms as an instructional tool enhanced students’ knowledge?” teacher comments included:

Outdoor learning integrated science across the curriculum, students remembered learning what they enjoyed the most, they studied various animals with binoculars and microscopes, they used outside stations to perform experiments. Students observed all living organisms, which seemed to enhance motivation in class. Science inquiry came more natural in all subject areas; experience was first-hand observing nature.

When teachers were asked to briefly describe if they believed the experience with pets would enhance student performance, they commented:

Inquiry transferred learning to real world application. Being outdoors gave them handson experiences they will always remember. Learning science outdoors brought content to the classroom from the playground. Hands-on learning enhanced process skills enabling them to apply what they learned to new situations. Students learned by “doing.” Authentic activities and manipulatives were used to master content.

When teachers were asked about the pets, and how they facilitated student learning, 78\% said, “Responsibility, love and caring for pets.” Teachers remarked:

Pets teach compassion, job training, love for living things, classifying, identifying adaptations, camouflage and the meaning of habitats. Pets helped to develop process skills. Working with pets taught children their needs such as how to maintain a cage, feeding the animals and providing a clean water supply. Pets teach empathy and excitement. Most of all pets teach unconditional love. Most teachers were positive but exit surveys indicated not all teachers were fond of having pets in their classroom. 
Although the focus of the study was on student learning, an interesting finding was that the act of teaching and working with students on the environmental playground, and designing lessons for implementation in that setting, influenced teacher knowledge about teaching science. Teacher candidates were able to articulate desired verbiage from both the affective and cognitive domains throughout their journals. More pictures of K-5 students' experiences and investigation of pets are included in Appendix B.

\section{Discussion}

This environment provided rich stomping grounds for learning process skills, especially observation and discovery, by interacting with pets firsthand (Green Schoolyards, 2010). Opportunities to practice scientific inquiry with experiential and concrete application, is critical for K-5 students (Bredekamp \& Rosegrant, 1995). The presence of pets on the playground and in the classroom provided many opportunities for observation and hands-on learning.

Throughout the review of teacher candidate response journals, there was evidence that the K-5 students were learning through exploration and experiences. The teacher candidates learned how to converse with K-5 students, especially in regard to asking higher-order questions that support scientific inquiry, and feeling more at ease. They learned effective skills of inquiry as they interviewed the students about what they had learned. Teacher candidates also learned how to use photographs to support the evidence in their journals, and how to use teachable moments as illustrated in figures. The field experience afforded them the opportunity to interact spontaneously with K-5 students, and at the same time integrate the principles of the 6E Inquiry method.

The K-5 students, through their experiences with pets and the environmental playground, learned not only responsibility to living organisms, but were able to make connections to concepts presented in their texts. The opportunity to engage in exploratory learning positively reinforced feelings of success.

Comments from the teachers indicated that the presence of pets and other living organisms, along with the opportunities of the environmental playground, provided opportunities to integrate science across the curriculum. Teachers were challenged to meaningfully teach science both indoors and outdoors. Teachers also noted the change in student dispositions toward pets and the environment, as a result of these experiences. 
The National Science Teachers Association (NSTA) standards for scientific inquiry, and the necessity to integrate safety in all activities, were integral parts of this program. NSTA's (2008) position statement refers to animal care, and encourages educators to make informed decisions about safety with all living organisms in the environment.

Current research reveals teaching children kindness toward animals will transfer to kindness toward people (Arbour, Signal, \& Taylor, 2009). Daly and Suggs (2010) suggest that “The ultimate goal of humane education programs is to foster compassionate values such as integrity, honesty and mercy” (p. 102). Melson (2001) argues that children derive emotional benefits through the child's relationship with pets. Findings from this study also suggest that having pets at school fostered a disposition of compassion that would transfer to the outside world. As well, the study illustrated the learning benefits of having numerous opportunities to interact with real animals and pets in school, which supports the argument of Searleman and Hermann (1994), who stated that real life experiences with a dog or butterfly, exceeded looking at pictures in a textbook.

\section{Implications for Future Research}

The findings of this study seem to suggest that instructional programs involving pets and living organisms bring positive results, and suggest possibilities for future research. The importance of all teachers in the school being on board with integration of pets and living organisms seemed to be important, and rules can become confusing to the student learners. Students still need explanations after they have explored their choices of experimentation (Trowbridge \& Bybee, 1990). Teachers appear to need more guidance on how to use teachable moments, and plan playful, meaningful activities for instruction, in regard to animal life.

The teachers’ greatest challenge was finding planning time to engage in meaningful activities both inside and outside the classroom. It was beneficial to use the 'less as more' rule when quality counts more than quantity. Today’s teachers have accountability requirements at all grade levels, and must cover certain skills to increase performance. Playing and experimenting with pets and living organisms transform prior knowledge connections to new information, which may develop conceptual change (Gunstone \& White, 2008). They can apply their process skills to all subjects. The specific impact on cognitive achievement related to pets and living organism instruction was not measured in this study, and needs further research. 


\section{Conclusion}

Student learners need to be able to explore, and at the same time develop scientific process skills in real world situations, observing and interacting with pets and other living organisms. The student learners' and teacher candidates' responses throughout the study showed an increased sensitivity to the feelings of other living organisms and classmates, which seemed to correlate with their positive experiences. The study also seemed to suggest that teachers who use the 6E inquiry method (Trowbridge \& Bybee, 1990) in combination with scientific processes, may need more professional development to effectively integrate experiences with animal life in the environmental science curriculums. Although this research was not designed for transference beyond the school setting, findings suggested that is a valuable practice to have pets in the school for student learning, and an effective means for teacher candidates to have exposure in their science education field experiences. This in turn could help student learners and teachers make significant progress in their future science classes, with indoor and outdoor teaching.

Dr. Robin McCartney is an Associate professor from the University of Louisiana at Lafayette in Lafayette, Louisiana. She obtained her $\mathrm{PhD}$ at Louisiana State University with a Specialist degree in Science Education. Her doctoral degree is in Curriculum \& Instruction with a minor in Educational Leadership. Her dissertation study was focused on information processing and "how" children think, not what they think.

Dr. Donna E. Dugger Wadsworth, PhD, is an endowed professor of special education and special education coordinator at the University of Louisiana at Lafayette. She is Past President of Louisiana Council for Exceptional Children and Division for Early Childhood and current treasurer for both organizations. She has numerous publications and presentations in both general and special education.

\section{References}

Arbour, R., Signal, T., \& Taylor, N. (2009). Teaching kindness: The promise of humane education. Society \& Animals, 17, 136-148.

Ascione, F. R. (1992). Enhancing children's attitudes about the humane treatment of animals: Generalization to human-directed empathy, Anthrozoos, 5(3), 176-191.

Bredekamp, S., \& Rosegrant, T. (1995). Reaching potentials: Transforming early childhood curriculum and assessment, Vol. 2. Washington, D. C.: National Association for the Education of Young Children.

Coyle, K. (Revised 2010). Environmental Literacy in America. Washington, D. C.: National Environmental Education and Training Foundation.

Cronin-Jones, L. (2000). The effectiveness of schoolyards as sites for elementary Science 
instruction. School Science and Mathematics, 100(4), 203-212.

Daly, B., \& Suggs, S. (2010). Teachers' experiences with humane education and animals in the elementary classroom: Implications for empathy development. Journal of Moral Education, 39(1): 101-112.

Green Schoolyards. (2010). Green schoolyards network. Retrieved from: http://greenschoolyardnetwork.org/

Gunstone, R., \& White, R. (2008). The conceptual change approach and the teaching of Science. In S. Vosniadou (Ed.), Handbook of research on conceptual change (pp. 619-628). New York, NY: Rutledge.

Holstein, J. A., \& Gubrium, J. F. (1995). The active interview. Thousand Oaks, CA: Sage. Inagaki, K. (1990). The effects of raising animals on children's biological knowledge. British Journal of Developmental Psychology, 8(1), 119-129.

Lincoln, Y. S., \& Guba, E. G. (1985). Naturalistic inquiry. Beverly Hills, CA: Sage.

Magnet School A+ Access Grant. (2007). Retrieved from www2.ed.gov/news/pressreleases/2007/09/09272007.html [Link no longer available.]

Melson, G. F. (2001). Why the wild things are: Animals in the lives of children. Cambridge, MA: Harvard University Press.

National Research Council. (1996). National Science education standards. Washington, DC: National Academy Press.

National Science Teachers Association. (2008). Position statement regarding animal care. Retrieved from http://www.nsta.org/about/positions/animals.aspx

Patton, M. Q. (2002). Qualitative research and evaluation methods. Thousand Oaks, CA: Sage.

Presutti, R. J. (2001). Prevention and treatment of dog bites. American Family Physician, 63(8), 1567-1575.

Rogers, D. L., Martin, Jr., R. E., \& Kousaleos, S. (1988). Encouraging Science through playful discovery. Day Care and Early Education, 16(1), 21.

Ross, M. E. (1997). Scientists at play. Science \& Children, 34(8), 35-38.

Searlemann, A., \& Herrmann, D. (1994). Memory from a broader perspective. New York, NY: McGraw-Hill.

Trowbridge, L. W., \& Bybee, R. W. (1990). Becoming a secondary Science teacher. Columbus, $\mathrm{OH}$ : Merrill. 


\section{Appendix A: Sample Data Analysis of Teacher Candidate Journals}

Sample Data Analysis of Teacher Candidate Journals

\begin{tabular}{|c|c|c|c|}
\hline $\begin{array}{l}\text { Impact on } \\
\text { participant } \\
\text { Group }\end{array}$ & $\begin{array}{l}\text { General } \\
\text { Coding } \\
\text { Categories }\end{array}$ & $\begin{array}{l}\text { Key } \\
\text { Descriptor } \\
\text { Phrases }\end{array}$ & Examples of Units of Data \\
\hline $\begin{array}{l}\text { Teacher } \\
\text { Candidates }\end{array}$ & $\begin{array}{l}\text { Facilitation } \\
\text { Experience }\end{array}$ & $\begin{array}{l}\text { Strategies } \\
\text { implemented } \\
\text { in teaching }\end{array}$ & $\begin{array}{l}\text { The lesson was on taste. Q-tips were } \\
\text { provided. Students took turns placing } \\
\text { various substances on the animal's } \\
\text { tongue. The children wanted to know } \\
\text { what tastes dogs liked the best. They } \\
\text { experimented by placing the same } \\
\text { substances on pieces of dog food and } \\
\text { recording responses. }\end{array}$ \\
\hline $\begin{array}{l}\text { Student } \\
\text { Learners }\end{array}$ & Assessment & $\begin{array}{l}\text { Student } \\
\text { Learner } \\
\text { Assessment }\end{array}$ & $\begin{array}{l}\text { Students used a worksheet and labeled } \\
\text { parts of the tongue. The dog preferred the } \\
\text { sweet taste on the dog food. The children } \\
\text { wanted to observe the dog's tongue to see } \\
\text { if it looked like the human tongue. }\end{array}$ \\
\hline $\begin{array}{l}\text { Students } \\
\text { and } \\
\text { Teachers }\end{array}$ & Discussion & $\begin{array}{l}\text { Student } \\
\text { Learner/Class } \\
\text {-room } \\
\text { Interactions }\end{array}$ & $\begin{array}{l}\text { Results were compared and discussed. } \\
\text { The children predicted the sweet taste. } \\
\text { One child asked if sweets would hurt the } \\
\text { dog. The teacher proceeded to tell them } \\
\text { dogs do not digest sugar like humans and } \\
\text { they could get sick. The children were } \\
\text { concerned. The teacher explained just a } \\
\text { drop was used and would not hurt the dog. } \\
\text { This was a sign of caring, respect, and } \\
\text { compassion for the dog, by the student. }\end{array}$ \\
\hline $\begin{array}{l}\text { Student } \\
\text { Learners }\end{array}$ & Application & $\begin{array}{l}\text { Teacher } \\
\text { candidate } \\
\text { reflections }\end{array}$ & $\begin{array}{l}\text { Children acted responsibly, applying the } \\
\text { substance with an eyedropper to ensure a } \\
\text { small dosage was used. The discussion } \\
\text { led to various answers related to real } \\
\text { world experiences such as, "My dog likes } \\
\text { food mixed with gravy.” Another student } \\
\text { stated their dog did not eat table food. } \\
\text { Students exhibited compassion toward } \\
\text { animal health. }\end{array}$ \\
\hline
\end{tabular}


Appendix B: Student Science investigations in the environmental playground
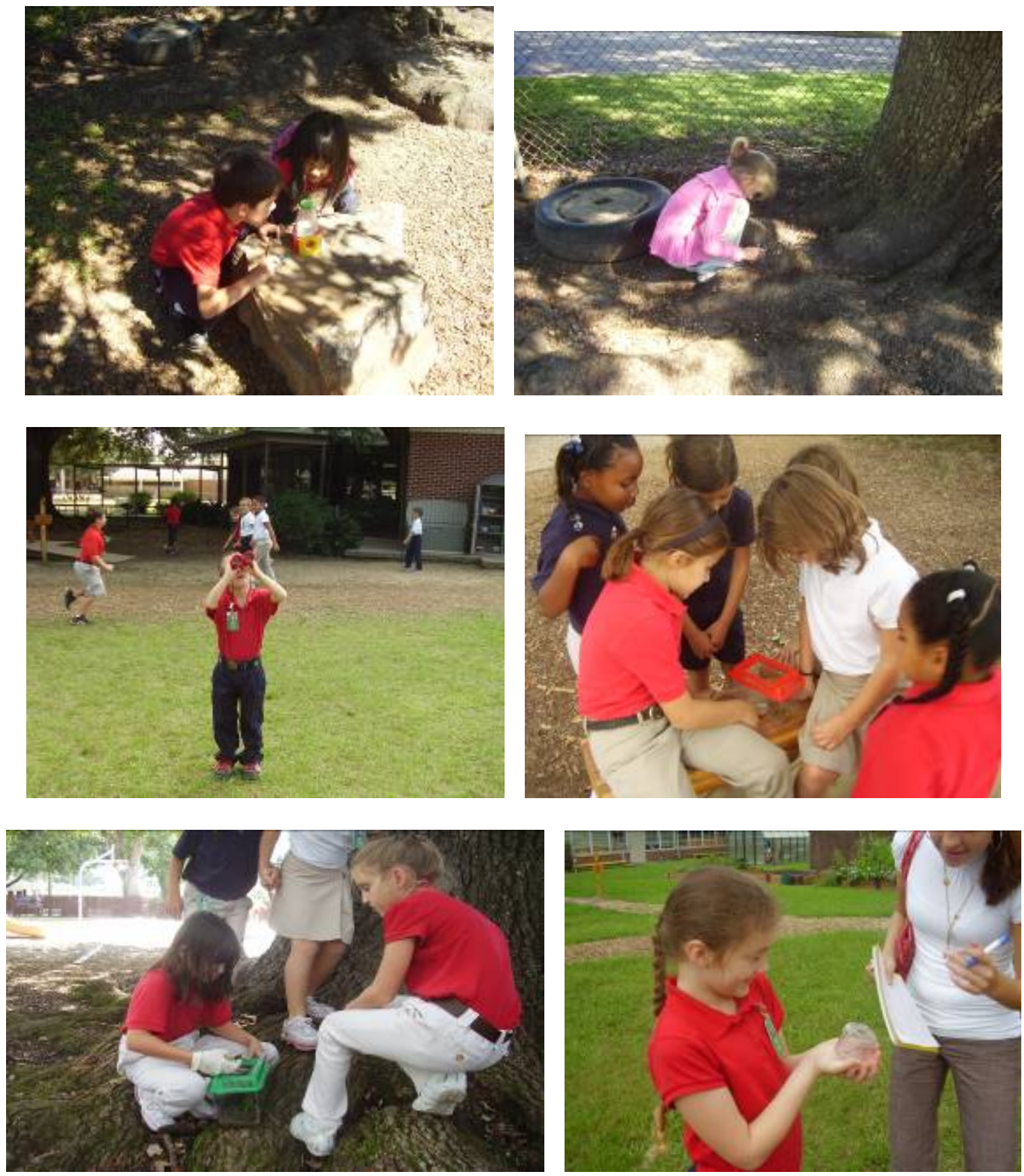
Learning Benefits for K-5 Students
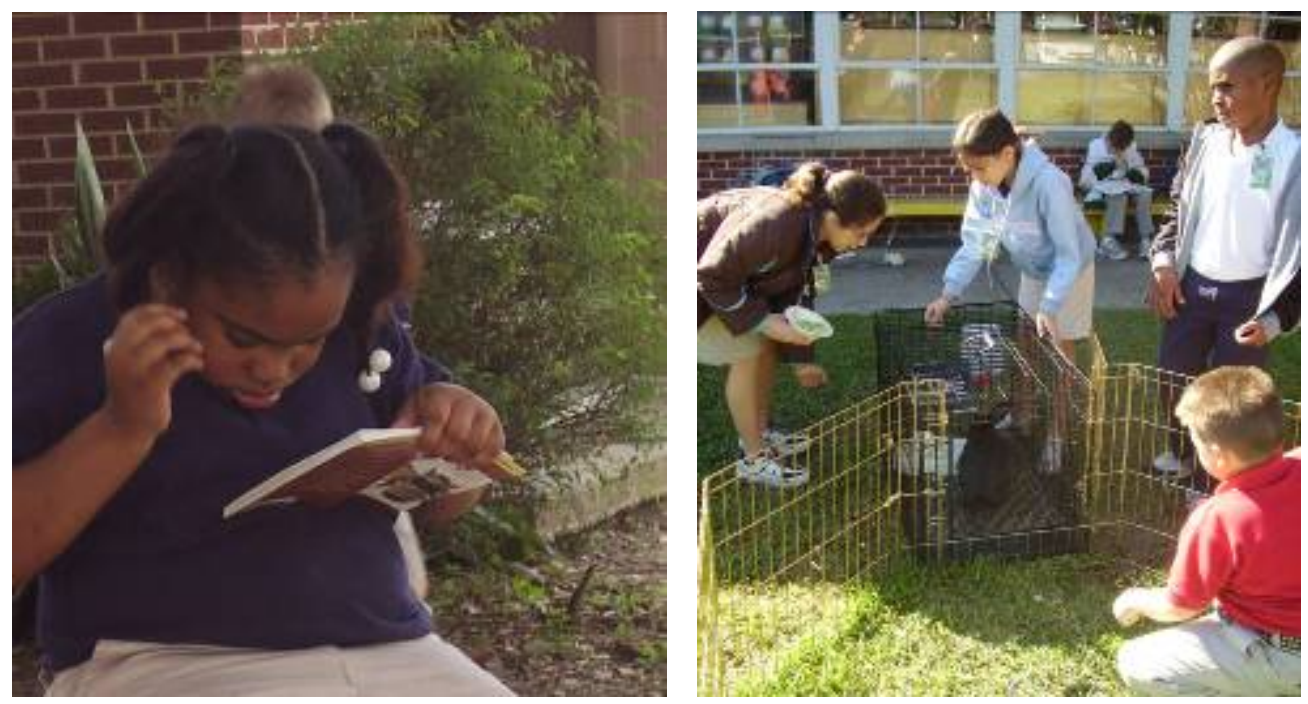